\title{
Bacterial cellulose/phytotherapic hydrogels as dressings for wound healing
}

\begin{abstract}
Healing is a complex process that involves cellular and biochemical events, and several medicines have been used to shorten healing time and avoid aesthetic damage. The development of an objective, non-invasive, and in-vivo examination method is urgently demanded towards helping the determination of the depth and degree of wound healing. This manuscript reports on a comparison of two wound dressings based on bacterial cellulose/ phytoterapic (Calendula officinalis and Jacaranda caroba) hydrogel applied to rat dorsum with bacterial cellulose hydrogel and untreated wound. The hydrogels were characterized by Scanning Electron Microscopy, Thermogravimetric Analysis and Fourier transformed - Infrared spectroscopy, and the results showed they are biocompatible and easy to attach, keep the site moist and do not damage the granulation tissue. According to the in vivo test, Bacterial Cellulose/Calendula officinalis hydrogel promoted a better wound healing and statistically significant differences in the tissue repair between treatments on the 3rd and 7th days (critical periods) after surgery. The results of the histological evaluation demonstrated a statistically significant difference for tissue inflammatory reaction between the treatments in the 3-day period. A statistically significant difference between the treatments in the evaluation of the quality, quantity and orientation of the collagen fibers was verified in the 7-day period. The hydrogels (especially bacterial cellulose with Calendula officinalis) yielded satisfactory results and, therefore, can contribute to the tissue repair of rat skin wounds.
\end{abstract}

Keywords: bacterial cellulose, Calendula officinalis, Jacaranda caroba, hydrogel, wound dressing, tissue repair
Volume 3 Issue 5 - 2019

\author{
Paula R Fontes,' Sidney JL Ribeiro, ${ }^{2}$ Ana \\ Maria M Gaspar ${ }^{1,2}$ \\ 'Programa de Pós Graduação Interunidades Bioengenharia, \\ Brazil \\ ${ }^{2}$ Universidade Estadual Paulista, Brazil
}

\begin{abstract}
Correspondence: Paula RF de S Moraes, Programa de Pós Graduação Interunidades Bioengenharia - EESC/FMRP/IQSC - USP,Av. Trabalhados São-carlense, 400, Arnold Schimidt, CEP: 13566-590, São Carlos, SP, Brazil, Tel 55 (16) 9 9|43-4863, Email paularfsm@usp.br
\end{abstract}

Received: August 31, 2019| Published: October 01, 2019
Abbreviations: TG, thermogravimetric analysis; FT-IR, fourier transform infrared; HPLC, high-performance liquid chromatography; SEM, scanning electron microscopy

\section{Introduction}

Skin, the largest organ of the human body, is formed mainly by epidermis and dermis and its main functions are assurance of mechanical protection and prevention against contamination., ${ }^{1,2}$ Wound healing begins from a skin-barrier disruption and is divided into inflammatory, proliferative, and maturation phases. The former consists in the recruitment of leukocytes to the site of the lesion. In the proliferative phase, the migration and proliferation of keratinocytes, fibroblasts, and endothelial cells results in reepithelization and formation of granulation tissue with a large quantity of type III collagen. Finally, in the maturation phase, most type III collagen fibers are substituted by type I fibers and the excess collagen is degraded by proteolytic enzymes that promote tissue remodeling. Despite some recent advances in the understanding of such basic processes, wound healing disorders continue to cause diseases and even death. ${ }^{3}$ Dressings play a substantial role in the conglutination of certain types of open wounds (e.g. traumatic, thermal or chronic wounds), since the moist, warm and nutritious environment of wound beds provides an ideal condition for microbial growth. The wound healing process can interfere with bacterial colonization and subsequent infection, which may cause an excessive and prolonged inflammatory response from the host tissues. The nature of lesions, patient's physiologic state, wound degree of infection and contamination and other disease processes can interfere with the cutaneous wound healing. ${ }^{4}$ The basic requirement for a material to be used for tissue engineering purposes is biocompatibility. Over the past two decades, significant advances have been made regarding the development of biodegradable polymers and biodegradability is one of the most important properties, since the scaffold should degrade with time and be replaced with newly regenerated tissues. ${ }^{5}$

In comparison with other biopolymers, e.g., collagen, chitosan and gelatin, bacterial cellulose (BC) displays excellent biological properties for tissue regeneration, mainly for the treatment of chronic and burn wounds. ${ }^{6,7}$ It is produced as never-dried membranes free of lignin and hemicelluloses, which show high elastic modulus and tensile strength when wet. ${ }^{8}$ Since the 80 s and 90 s, BC-based dressings (as Biofill ${ }^{\circledR}$ (Fibrocel, Brazil)) have been used as temporary dressings for the treatment of skin wounds mainly in burns, graft and chronic ulcers. ${ }^{6,-11}$ The use of medicines and plants for the treatment of several diseases, even for favoring wound healing, is an ancient practice. Calendula officinalis (CO) was used in the Middle Ages for wound healing and treatment of inflammatory skin diseases. In Germany, the topical use of marigold preparations is still very popular. $C$. officinalis is a medicinal plant with diverse biological activities. ${ }^{12}$ Its experimental topical use in rats as a cream preparation showed both anti-inflammatory and wound-healing effects ${ }^{13}$ and faradiol esters were identified as the most potent single substances in the marigold extract. ${ }^{14}$ Jacaranda leaves macerated in alcohol (cachaça) have been widely applied for cicatrization and ingestion in treatments of ulcers. ${ }^{15,16}$ In Brazil, the inhabitants of Vale do Ribeira, São Paulo, have 
employed this species for combating syphilis, wounds and ulcers. ${ }^{15}$ Despite the existence of modern and advanced technologies in the pharmaceutical industry, market products that stimulate the wound repair process are still limited. This study evaluated the topical effect of two hydrogels based on bacterial cellulose and two phytoterapics (Calendula officinalis (CO) and Jacaranda caroba (JC)) on the healing process of rat skin wounds and the organization of collagen fibers in the injured tissue.

\section{Materials and methods}

\section{Plant material}

Hydroalcoholic tincture $(20 \%$ extract in $70 \%$ ethanol $)$ of Calendula officinalis flowers was commercially obtained from Calêndula Pharmacy (São Carlos, SP, Brazil). Dried extract of $J$. caroba leaves, collected in Minas Gerais state, Brazil, was obtained from Universidade Federal de Minas Gerais and Jacaranda caroba tincture (20\% extract in $70 \%$ ethanol) was prepared at the Institute of Chemistry from São Carlos, at Universidade de São Paulo.

\section{High-performance liquid chromatography (HPLC)}

The phytochemical profile of the tinctures was determined by a Shimadzu (Kyoto, Japan) liquid chromatography system equipped with an LC-10 AT VP solvent pump unit and an SPD-10A VP UV-Visible detector operating at $340 \mathrm{~nm}$. Samples were manually injected by a Rheodyne injector $(20 \mu \mathrm{L}$ loop) and the compounds were separated in a C18 Hypersyl BDS-CPS cyano column $(250 \mathrm{~mm}$ $\mathrm{x} 4.6 \mathrm{~mm}, 5 \mu \mathrm{m})$ (Thermo Electron Corporation, USA). The mobile phase was methanol-water $(20: 80, \mathrm{v} / \mathrm{v})$ for $J$. caroba and $(25: 85$, $\mathrm{v} / \mathrm{v}$ ) for $C$. officinalis at a $1 \mathrm{~mL} / \mathrm{min}$ flow rate for $60 \mathrm{~min}$, and data were collected by LC Real Time Analysis software. All procedures were conducted at the Institute of Chemistry from São Carlos, at Universidade de São Paulo.

\section{Preparation of hydrogels}

Bacterial cellulose (BC) was obtained from cultures of Gluconacetobacter hansenii (ATCC 23769 strain). G. hansenii bacteria were cultivated in $100 \mathrm{~mL}$ flasks with a $20 \mathrm{~mL}$ static culture medium for $120 \mathrm{~h}$ at $28^{\circ} \mathrm{C}$. The nutrient medium contained $2 \mathrm{wt} \%$ glucose, $0.5 \mathrm{wt} \%$ peptone, $0.5 \mathrm{wt} \%$ yeast extract, $0.27 \mathrm{wt} \%$ disodium hydrogen phosphate, and $0.115 \mathrm{wt} \%$ citric acid. Bacterial cellulose pellicles formed on the air/liquid interface were harvested and purified by immersion in a $2 \mathrm{wt} \% \mathrm{NaOH}$ solution at $80^{\circ} \mathrm{C}$ for $1 \mathrm{~h}$. Subsequently, they were immersed in a $1 \mathrm{wt} \% \mathrm{NaClO}$ solution for $30 \mathrm{~min}$, washed with deionized water and sterilized by autoclave at $120^{\circ} \mathrm{C}$ for $15 \mathrm{~min} . \mathrm{BC} / \mathrm{CO}$ and $\mathrm{BC} / \mathrm{JC}$ hydrogels were prepared with sterilized instruments. Never-dried BC membranes were triturated in an aqueous medium by an Ultra Turrax T18 Ika high-speed disperser element. The BC particles suspension was sieved (37mesh) for the removal of excess water. The $\mathrm{BC}$ pulp was used in the preparation of the hydrogels. $0.2 \mathrm{wt} \%$ of Nipagin ${ }^{\circledR}$ (Henri Farma, Brazil) were solubilized in $5 \mathrm{wt} \%$ propyleneglycol (Pharma Nostra, Brazil) under orbital shaking at $50^{\circ} \mathrm{C}$. The mixture was poured into a beaker containing $10 \mathrm{wt} \%$ of bacterial cellulose pulp under mechanical stirring at RT. $3 \mathrm{wt} \%$ of Natrosol (Hydroxyethylcellulose) (Pharma Nostra, Brazil) were slowly added under shaking until the obtaining of gel consistency at RT. $10 \mathrm{wt} \%$ of CO and JC tincture and deionized water were added to each treatment. The hydrogels were kept under shaking for $3 \mathrm{~min}$ at RT and then stored in a sterile vial.

\section{Physicochemical characterization}

Scanning electron microscopy (SEM): Samples of hydrogels were freeze-dried $\left(-40\right.$ to $\left.-50^{\circ} \mathrm{C}\right)$ at constant weight prior to examination by scanning electron microscopy. SEM images were obtained by a JEOL/EO - JSM-6610 scanning electron microscope for the analysis of changes in the micro fibrillar structure in lyophilized samples coated with a $10 \mathrm{~nm}$ carbon layer by a metallizer Balsers model CDS 050 . The morphology was observed at $15 \mathrm{kV}$ accelerating voltage.

Thermogravimetric analysis (TG): The thermogravimetric curves of the samples were recorded by a TA SDT 2960 from TA Instruments Co. All samples were heated in alumina pans at a $25{ }^{\circ} \mathrm{C}$ to $800{ }^{\circ} \mathrm{C}$ temperature range under nitrogen atmosphere $\left(100 \mathrm{~mL} \mathrm{~min}^{-1}\right.$ flow rate) and $10{ }^{\circ} \mathrm{C} \mathrm{min}^{-1}$ heating rate.

Fourier transform infrared (FT-IR): Fourier transform infrared (FT-IR) spectra were obtained with lyophilized powdered samples by a Perkin Elmer Spectrum 2000 spectrophotometer. Pellets were prepared from mixtures of the samples and $\mathrm{KBr}$ (1:100 in weight). Sixty-four scans were accumulated at $1 \mathrm{~cm}^{-1}$ resolution in the 4000 to $400 \mathrm{~cm}^{-1}$ range.

Cytotoxicity and cell viability: The essay was performed at the Department of Physiology of the Federal University of São Carlos under the supervision of $\mathrm{PhD}$ Caroline Faria Bellani.

Cell culture: L929 mouse-derived fibroblasts were maintained in a DMEM medium (Life Technologies ${ }^{\mathrm{TM}}$ ) supplemented with $10 \%$ fetal bovine serum (Vitrocell $\left.{ }^{\circledR}\right)$, penicillin-streptomycin (1\%) and amphotericin b $(2 \mathrm{mg} / \mathrm{L})$.

\section{Preparation of the hydrogel extracts}

The hydrogel samples were dissolved in a 10\% (v/v) DMEM culture medium for 48 hours under magnetic stirring. The extracts were kept under refrigeration at $8^{\circ} \mathrm{C}$ and applied to the respective groups of cells to be studied.

\section{Proliferation and cell viability}

The AlamarBlue ${ }^{\circledR}$ (Life Technologies ${ }^{\mathrm{TM}}$ ) assay checked the influence of the hydrogels on the cell growth and viability over time. AlamarBlue ${ }^{\circledR}$ is a reagent with an oxidation-reduction indicator (REDOX) that both fluoresces and changes its color in response to chemical reduction, which is the result of cell growth in a culture medium. A continuous cell growth maintains a reduced environment (fluorescent, red), whereas the inhibition of cell growth maintains an oxidized (non-fluorescent, blue) environment. The AlamarBlue ${ }^{\circledR}$ assay quantitatively measures the relative proliferation and viability or cytotoxicity of various human, animal, bacterial or fungal cell lines. ${ }^{17}$ L929 fibroblasts were counted and plated at 1x104 per 24well microplate wells for the experiments. The cells were allowed to adhere for 24 hours at $37^{\circ} \mathrm{C}+5 \% \mathrm{CO}_{2}$ and formed a layer at the cells at the bottom of the well. The hydrogel extracts were applied on them after 24 hours. Three samples, namely pure bacterial cellulose, $\mathrm{BC} / \mathrm{P}$, bacterial cellulose + Jacaranda caroba dye, BC/JC, bacterial cellulose + Calendula officinalis tincture, $\mathrm{BC} / \mathrm{CO}$ were used for each hydrogel. The extract of the hydrogels was changed every two days. The culture medium was aspirated at each time point for the AlamarBlue ${ }^{\circledR}$ assay, and $500 \mu \mathrm{L}$ of $10 \% \mathrm{v} / \mathrm{v} \%$ AlamarBlue solution were dissolved in DMEM culture medium (supplemented as described above) per well. The plates were maintained at $37^{\circ} \mathrm{C}+5 \% \mathrm{CO}_{2}$ for 4 hours, and then $100 \mu \mathrm{L}$ of the supernatant from each well were transferred to 
a 96-well microplate. $100 \mu \mathrm{L}$ of completely reduced AlamarBlue ${ }^{\circledR}$ solution were also added to four wells of the new microplate for the calculation of the relative reduction percentage. The microplate was obtained through the autoclaving of the solution for 15minutes, according to the manufacturer's guidelines. ${ }^{17}$ The fluorescence values were measured by a fluorimeter (SpectraMax Gemini XS - Molecular Devices) using $544 \mathrm{~nm}$ excitation and 590nm emission spectrums. The values obtained from each sample were compared to the average of the fluorescence values obtained from the completely reduced AlamarBlue ${ }^{\circledR}$ solution. The assay was performed at periods of 3, 7, 14 and 21 days after the start of cell culture and data were analyzed by GraphPad Prism (GraphPad Software, La Jolla California USA) at a 5\% significance level and two-way ANOVA with Tukey post-test.

\section{Animal experimentation}

The experiment was approved by the Ethics Committee on Animal Experimentation at the Faculty of Pharmaceutical Sciences at Araraquara, UNESP, São Paulo, Brazil. Thirty-two adult male rats (Rattus norvegicus, albinus, Holtzman) weighing approximately $250 \mathrm{~g}$ were used and randomly allocated into four groups, namely $\mathrm{BC} / \mathrm{JC}$ hydrogel (GI), blood clot (negative control) (GII), BC/ $\mathrm{CO}$ hydrogel (GIII) and pure (P) $\mathrm{BC}$ hydrogel (positive control) (GIV). Eight animals were studied per group/period. The periods for macroscopic and histological analyses were 3, 7, 15 and 30 days after surgery. General anesthesia was induced by intramuscular injections of ketamine hydrochloride $\left(25 \mathrm{mg} \mathrm{kg}^{-1}\right.$; Agener União, Brazil) and xylazine hydrochloride (5 $\mathrm{mg} \mathrm{kg}^{-1}$; Bayer, Brazil). All surgical procedures followed standard aseptic protocols. After the shaving and preparation of the dorsal region, two wounds were made ( $2 \mathrm{~cm}$ distance between them) in its medium line by a circular $10 \mathrm{~mm}$ diameter scalpel. The depth of the wound reached epidermis, dermis, hypodermis and muscular layers until fascia superficialis. Each animal received two groups. For the first analysis, $\mathrm{BC} / \mathrm{JC}$ hydrogel wound dressing (GI) was applied in the superior wound and the inferior wound was filled with a blood clot (GII), whereas for the second analysis, $\mathrm{BC} / \mathrm{CO}$ hydrogel wound dressing (GIII) was applied in the superior wound and the inferior wound received pure $\mathrm{BC}$ hydrogel (GIV). The wound dressings were applied once per day during the whole treatment period. The animals were transferred to separate cages properly isolated and identified and kept at controlled room temperature $\left(22 \pm 2^{\circ} \mathrm{C}\right)$, humidity $(60-70 \%)$ and light $(12 \mathrm{~h}$ light/dark cycles) under appropriate conditions of food, water and hygiene. Their recovery was monitored daily. In the immediate postoperative period, all animals received an intra peritoneal administration of a single dose of $12.5 \mathrm{mg} \mathrm{kg}^{-1}$ tramadol analgesic (Medley Pharmaceutical Industry Ltda., Brazil).After 3, 7, 15 and 30 days, four animals in each group were anesthetized again, according to the protocol, for macroscopic analysis and removal of wounds. Subsequently, they were euthanized with an intramuscular administration of Thiopentax (thiopental,

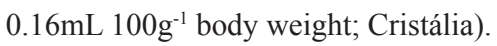

\section{Macroscopic analysis}

The wounds were macroscopically evaluated 3, 7, 15 and 30 days after surgery for analyses of the redness in the wound region, presence of excessive exudate and humidity. The lesions were photographed after the pre-euthanasia anesthesia procedure by a Sony digital camera (16.2-megapixel Cyber-Shot model), with the defined scale of all animals in each period. ImageJ software was used for the analysis of the area of lesions, whose measures were tabulated and statistically evaluated by GraphPad Prism software (GraphPad Software, La Jolla
California USA). The level of statistical significance was established at $5 \%$. The quantitative data obtained were tested for normality by Lilliefors Test. Two-way ANOVA followed by post-hoc Tukey were then applied for the evaluation of differences among the groups and effect of the follow-up period.

\section{Histological analysis}

After euthanasia, the areas of the wounds were surgically removed, fixed in a Bouin solution for $48 \mathrm{~h}$ and processed according to the histological routine for light microscopy. The specimens were cut into semi-serial $6 \mu \mathrm{m}$ sections in the longitudinal direction of the skin and stained with hematoxylin-eosin (H\&E). They were analyzed and photographed under a microscope (Olympus X51; Olympus, WA) coupled to a digital camera (Olympus DP71, 12.5 Mpixels; Olympus) of $6.3 \times$ magnification. The images were captured by Leica Application Suite software. Scores of inflammatory reaction evaluations were given according to the inflammation degree (scores 0-4: 0 - no reaction; 1 - very slight reaction; 2 - mild reaction; 3 - moderate reaction; 4 - marked reaction) and ASTM F981-04 standards. ${ }^{18}$ The statistical analysis was descriptive and consisted in the division of the samples of each lamina (six laminas of each specimen with six cuts) according to 3, 7 and 15 - day periods. The first and last cuts were discarded. The tissue repair pattern was also evaluated regarding quality, quantity and orientation of collagen fibers and epithelium regeneration. The scores used are shown in Tables $1 \&$ 2. GraphPad Prism software (GraphPad Software, La Jolla California USA) was used for the statistical analysis and the level of statistical significance was established at $5 \%$. The data obtained were tested for normality by Lilliefors Test. ANOVA test was used for the analysis of inflammation degree and t-test was applied as a post-test. KruskalWallis and Dunn tests analyzed the tissue repair standard (quality, quantity and orientation of collagen fibers) and tissue repair standard (epithelium reconstitution), respectively.

Table I Classification of the tissue repair pattern regarding quality, quantity and orientation of collagen fibers

\begin{tabular}{ll}
\hline Classification & Score \\
\hline Absence of fibers & 0 \\
Disorganized fibers & 1 \\
Poorly organized fibers & 2 \\
Medium organization of fibers & 3 \\
Well organized fibers & 4 \\
\hline
\end{tabular}

Table 2 Classification of the tissue repair pattern in relation to the epithelial repair

\begin{tabular}{ll}
\hline Classification & Score \\
\hline Unrepaired & 0 \\
Healing process & $\mathrm{I}$ \\
Repaired & 2 \\
\hline
\end{tabular}

\section{Results and discussion}

\section{High-performance liquid chromatography (HPLC)}

Methanolic extracts of $C$. officinalis flowers and $J$. caroba leaves were characterized by HPLC. The chromatographic profile obtained for tinctures and extracts under standard conditions, called "digital printing", revealed their qualitative constitution and characterized the material analyzed. The chromatographic profiles of methanolic extracts of $C$. officinalis flowers and $J$. caroba leaves showed the 
presence of substances with a predominance of peaks ranging from 17 to $32 \mathrm{~min}$ and 13 to $26 \mathrm{~min}$, respectively. No peaks of significant intensities were observed after this period. The profile of the methanolic extract of $C$. officinalis flowers revealed a predominance of 8 peaks (Figure 1A). The chromatogram showed peaks of 31.40 min retention time and ultraviolet spectrum of $254 \mathrm{~nm}$ maximum wavelength, thus demonstrating the main substances present in the methanolic extracts of the $C$. officinalis leaves belong to this class. A phytochemical study of the extract of Calendula officinalis detected the presence of flavonoids, carotenoids and terpenoids. According to Copp ${ }^{19}$ terpenoids are the secondary metabolites considered the main promising class of anti mycobacterial activity. Studies conducted by Higuchi ${ }^{20}$ revealed the main terpenoids isolated that showed an inhibitory activity of Mycobacterium growth were lupeol, ursolic and oleanolic acids. Their presence in the methanolic extracts of Calendula officinalis flowers suggests they are also responsible for an anti mycobacterial action. The results corroborated the popular use of C. officinalis for the treatment of infections caused by microorganisms and revealed substances of the terpenoid class are responsible for the antimicrobial action.

A phytochemical study of the extract of $J$. caroba detected the presence of phytochinoids, triterpenes, phenols and flavonoids. The profile of the methanolic extract of those leaves showed predominance of 10 peaks (Figure 1B). The chromatogram revealed peaks of $18.95 \mathrm{~min}$ retention time and ultraviolet spectrum of 254 $\mathrm{nm}$ maximum wavelength, thus demonstrating the main substances present in the methanolic extracts of $J$. caroba leaves belong to this class. According to Simões ${ }^{19}$ some flavonoids are responsible for an antitumor activity and may also act as antiviral, antibacterial, antihemorrhagic, hormonal, vasodilator, anti-inflammatory, antimicrobial and antioxidant. Carotenoids exert a favorable effect on the epithelization process, influencing the cell cycle progression of fibroblasts. ${ }^{21,22}$ The content of compounds, as flavonoids, carotenoids, terpenoids, triterpenes and phenols in the present study was similar to those reported in the literature. External factors, such as temperature, wind, soil, latitude and altitude, and technical factors, as planting, fertilization, harvesting season and growth stage can influence the chemical composition of the plants interfering with the content of the active principle and production of biomass. ${ }^{23}$

\section{Physical-chemical characterization}

Scanning electron microscopy (SEM): Figure 2 shows SEM images of lyophilized pure $\mathrm{BC}, \mathrm{BC} / \mathrm{JC}$ and $\mathrm{BC} / \mathrm{CO}$ hydrogels, respectively. The porosity of the hydrogels is an important factor in the modulation of cell and tissue interactions and penetration of cells into scaffold. ${ }^{24}$ The images display a porous material, typical of a hydrogel, and the SEM micrographs show a structure of randomly disposed fiber arrangements, with some more compact points. Interconnected pores in three-dimensional directions throughout the samples are fundamental for the tissue repair, since such a morphology enables the in growth of fibroblasts. ${ }^{25}$ According to Figure 2, the surface of (a) apparently shows more compact fibers than (b) and (c) and the pores in the cross-section of (A) and (B) seem larger than those in (C). Distributed and interconnected fibers in layers are more visible in (A). Previous studies have shown hydrogels with large pores promote a better cell penetration and formation of new tissues within the microstructure of the scaffold, in comparison to hydrogels of lower porosity. ${ }^{24}$
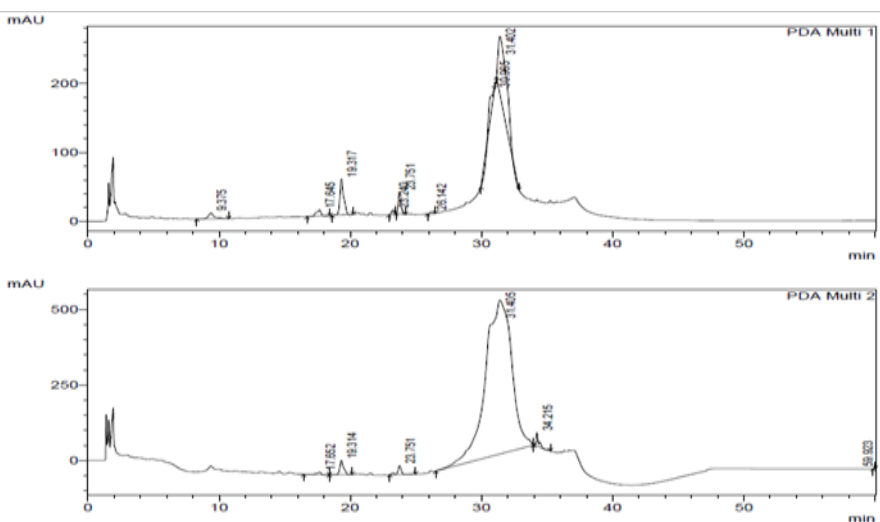

1 PDA Mutt $1 / 254 \mathrm{~nm} 4 \mathrm{nmm}$
2 PDA MUtti $2 / 220 \mathrm{~nm} 4 \mathrm{~nm}$

(A)
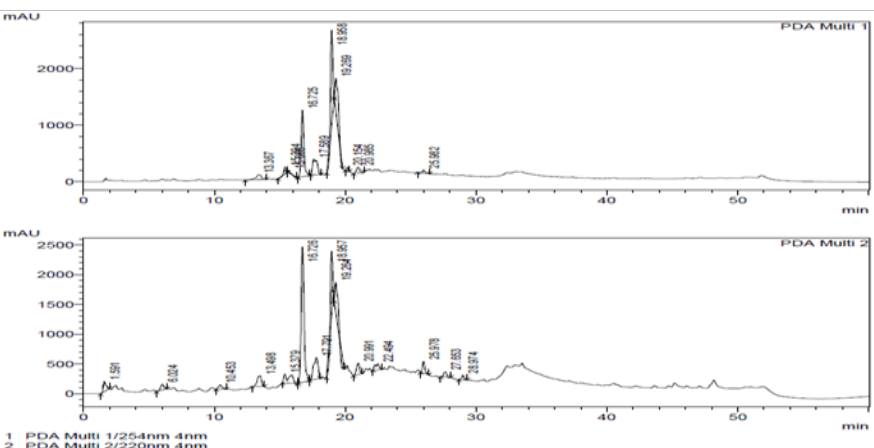

(B)

Figure I HPLC profile: (A) C. officinalis and (B) J. caroba at $254 \mathrm{~nm}$.
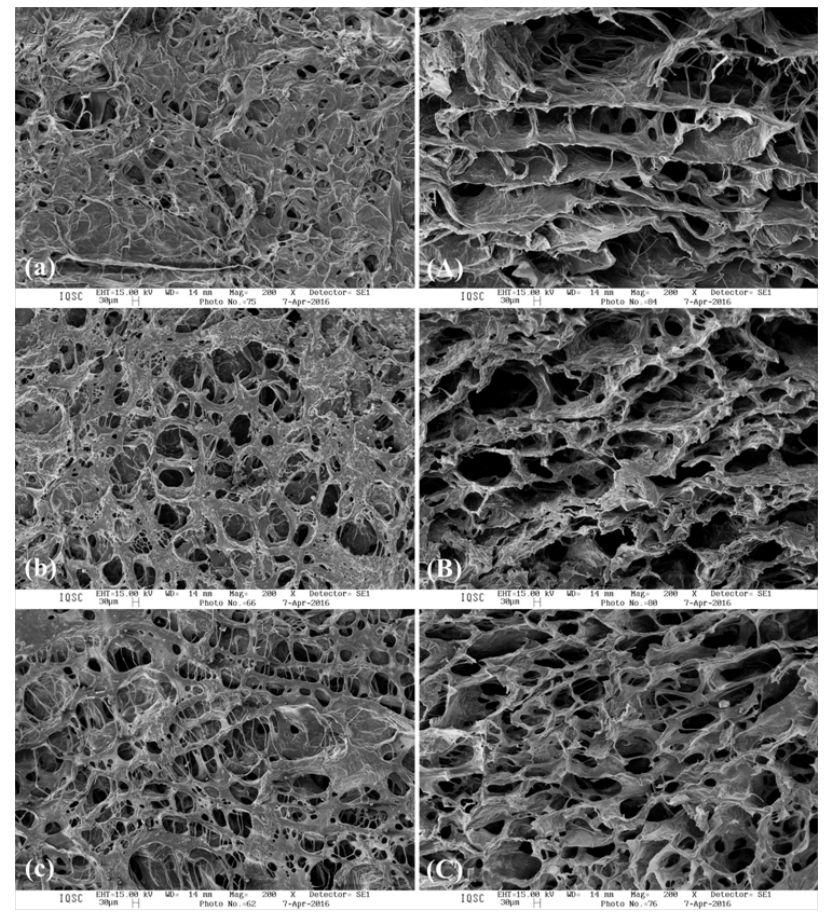

Figure 2 SEM surface images of $B C / P(A), B C / J C(B)$ and $B C / C O(C)$. SEM cross-section images (A, B and $C$ ). 
Thermogravimetric analysis (TG): The samples were heated at a constant temperature until their mass had changed. At this point, the temperature stopped increasing, so that the mass could stabilize. The temperature increased again until the next mass change. Figure 3 shows the thermogravimetric curves obtained at $10{ }^{\circ} \mathrm{C} / \mathrm{min}$ heating rate for the hydrogels. The three stages observed for the samples are attributed to:

\section{I - Loss of water;}

II. II - Loss by decomposition; and

III. III - Carbonization.

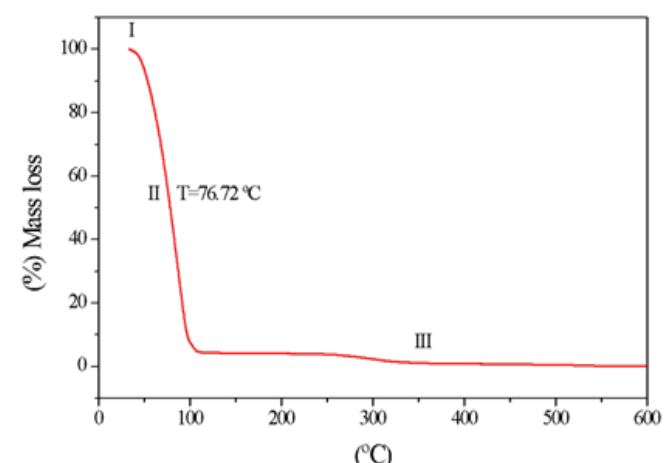

(A)

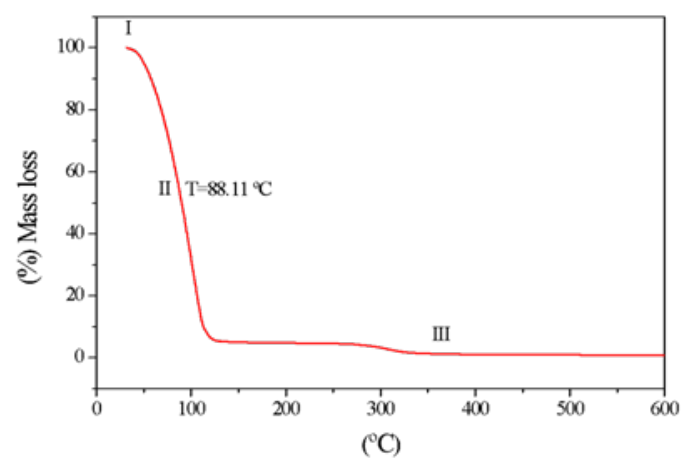

(B)

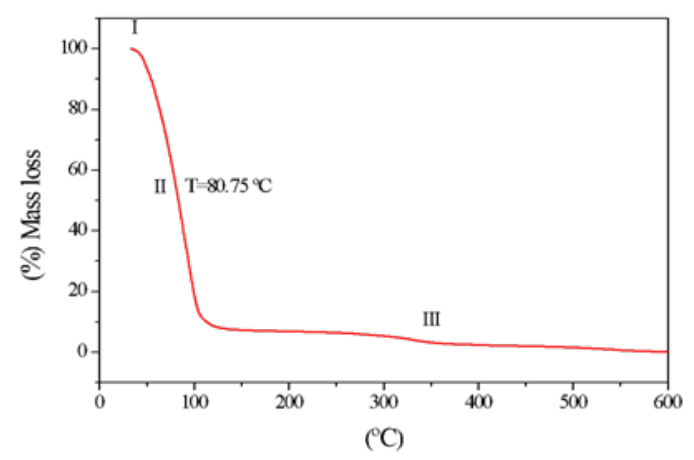

(C)

Figure 3 TG curves: (a) BC/P, (b) BC/CO and (c) BC/JC.
The thermogravimetric waves of $\mathrm{BC} / \mathrm{P}, \mathrm{BC} / \mathrm{JC}$ and $\mathrm{BC} / \mathrm{CO}$ hydrogel samples showed in stage II, where the largest mass loss occurs, were achieved at $76.72{ }^{\circ} \mathrm{C}, 80.75^{\circ} \mathrm{C}$ and $88.11^{\circ} \mathrm{C}$ temperatures, respectively. $\mathrm{BC} / \mathrm{CO}$ hydrogel showed a better result compared to $\mathrm{BC} / \mathrm{P}$ and $\mathrm{BC} / \mathrm{JC}$ hydrogels, since it supported temperatures of $13 \%$ and $8.3 \%$, respectively, for its decomposition. However, $\mathrm{BC} / \mathrm{JC}$ is better than $\mathrm{BC} / \mathrm{P}$ (positive control) because it has a temperature of $13 \%$ more for its total decomposition.

Fourier transform infrared (FT-IR): Infrared radiation (IR) corresponds to part of the electromagnetic spectrum between the visible and microwave regions. Each functional group absorbs a given characteristic frequency, which enables the IR to characterize the functional groups of a standard or an unknown material ${ }^{26}$ through a graph of intensity of radiation versus frequency. The FT-IR technique is not destructive and accepts sparingly soluble sample spectra in solid state films, as lyophilized hydrogels. ${ }^{27}$ According to Figure 4, which shows similar infrared spectra among the lyophilized samples of the hydrogels, the chemical composition of $\mathrm{BC}$ did not change, i.e., its properties were maintained even after the addition of the dyes. The samples exhibited typical bands for proteins at approximately 1656 and $1547 \mathrm{~cm}^{-1}$, related to the $\mathrm{C}=\mathrm{O}$ amide I stretch and $\mathrm{N}-\mathrm{H}$ deformation for amide II, respectively. These bands were observed with little intensity difference between the sample spectra, but the $\mathrm{BC} /$ JC hydrogel was slightly larger. The $\mathrm{C}-\mathrm{H}$ band of aromatic is attributed to the band around $2922 \mathrm{~cm}^{-1}$. The spectra showed bands around $1600-$ $1700 \mathrm{~cm}^{-1}$, characteristic of a protein, which indicates the stretching of a carbonyl; at $1450 \mathrm{~cm}^{-1}$, it indicates the presence of stretches of the phenyl ring $(\mathrm{C}=\mathrm{C})$. The absorption band at $1048 \mathrm{~cm}^{-1}$ is characterized by the $\mathrm{C}-\mathrm{H}$ bond of the ring. Despite some slight variations in the intensity of the detected vibrational modes, the values obtained are in agreement with those reported in the literature. ${ }^{28}$ The increase in the bands observed in the three samples may be related to the formation of hydrogen bonds between the hydroxyls of bacterial cellulose. ${ }^{29}$

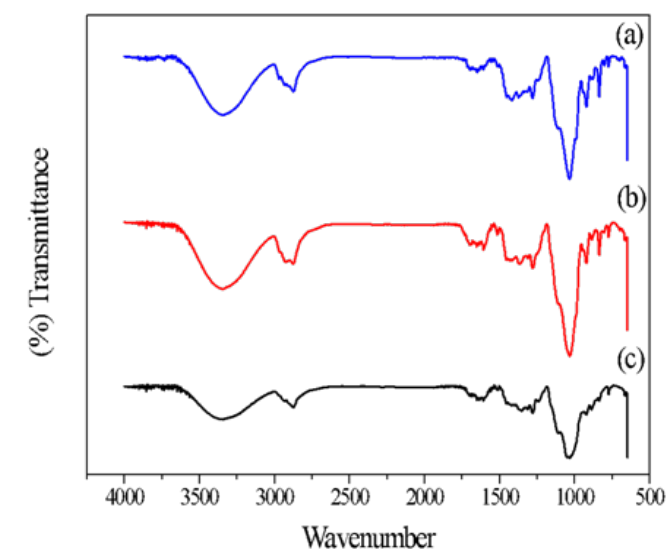

Figure 4 FT-IR spectra: (a) BC/P, (b) BC/JC and (c) BC/CO.

Cytotoxicity and cell viability: L929 cells proliferated with the hydrogels extracts of pure bacterial cellulose $(\mathrm{BC} / \mathrm{P})$, bacterial cellulose with Calendula officinalis $(\mathrm{BC} / \mathrm{CO})$ dye and bacterial cellulose with Jacaranda caroba dye (BC/JC) uniformly up to 14 days after plating. The results show the final concentration of Calendula extract, estimated at $0.7 \mathrm{~m} / \mathrm{v} \%$, is not toxic to cells. The toxicity of repeated doses of extracts of Calendula officinalis flowers can be considered low, however, care must be taken in oral administration for prolonged periods, especially in individuals with liver, renal or hematological 
problems. ${ }^{30}$ The acute toxicity of the hydroalcoholic extract of Calendula officinalis (extracted with $30 \%$ ethanol, and with a plant extract: extractor liquid ratio of 1:1) administered subcutaneously was reported to be $45 \mathrm{mg}$ in mice. ${ }^{30}$ Silva detected a low toxicity in the hydroalcoholic extract of $C$. officinalis flowers. They evaluated the oral administration of water extract at doses of $0.025 ; 0.25 ; 0.5$; and $1.0 \mathrm{~g} / \mathrm{kg}$ daily for 30 days in male Wistar rats and observed both hematological and biochemical parameters remained within normal limits. ${ }^{31}$ According to Brazil,${ }^{30}$ an unpublished Cosmetic, Toiletry and Fragrance Association occlusion test involving aqueous extract of $10 \%$ C. officinalis performed in nine rabbits showed the primary index of dermal irritation was zero. Fronza et al. (2009) demonstrated the effects of the increase of $\mathrm{C}$. officinalis ethanolic extract (10 g plant material $/ 150 \mathrm{~mL}$ extractive solvent) fibroblast proliferation, at a $10 \mu \mathrm{g} /$ $\mathrm{mL}$ concentration in the microplates, were 64.3 and $74.5 \%$ in relation to the control treatment $(0.25 \% \mathrm{DMSO})$. According to Hernandes the extract of $J$. Caroba showed more cytotoxicity in comparison with other specimens of the Bignoniaceae family. However, it did not show signs of toxicity in our in vivo test, which agrees with the results of the macroscopic and histological analysis that revealed a better tissue regeneration rate (Figures $5 \& 6$ ) than the control (clot) for periods of 3 and 7 days, and relative to the $\mathrm{BC} / \mathrm{P}$ hydrogel for the 3-day period. On day 21 , the number of viable cells cultured with BC/JC (Figure 7) decreased as well as for the negative control (untreated), whereas for $\mathrm{BC} / \mathrm{P}$ and $\mathrm{BC} / \mathrm{CO}$, the relative fluorescence remained stable. As the decrease also occurred for untreated cells, the decrease in the relative fluorescence for microplates with $\mathrm{BC} / \mathrm{JC}$ hydrogel can be attributed to the cell dynamics. Under in vitro conditions, the cells towards filling all available space. The proliferation stabilizes and decreases due to the effect of the apoptosis signaling cascade. Apoptosis, i.e., the process of cell death, is fundamental for the development and function of multicellular organisms. ${ }^{34,35}$ Since the relative amount of viable cells remained stable for the other hydrogels $(\mathrm{BC} / \mathrm{P}$ and $\mathrm{BC} / \mathrm{CO})$, aspects, as density and polymerization of such hydrogels should be investigated. If they are higher than those of $\mathrm{BC} / \mathrm{JC}$, a larger amount of bacterial cellulose is in contact with the cells, which increases the surface on which the cells can proliferate and maintains cell culture in vitro longer than the flat surface of the control well. ${ }^{36,37}$
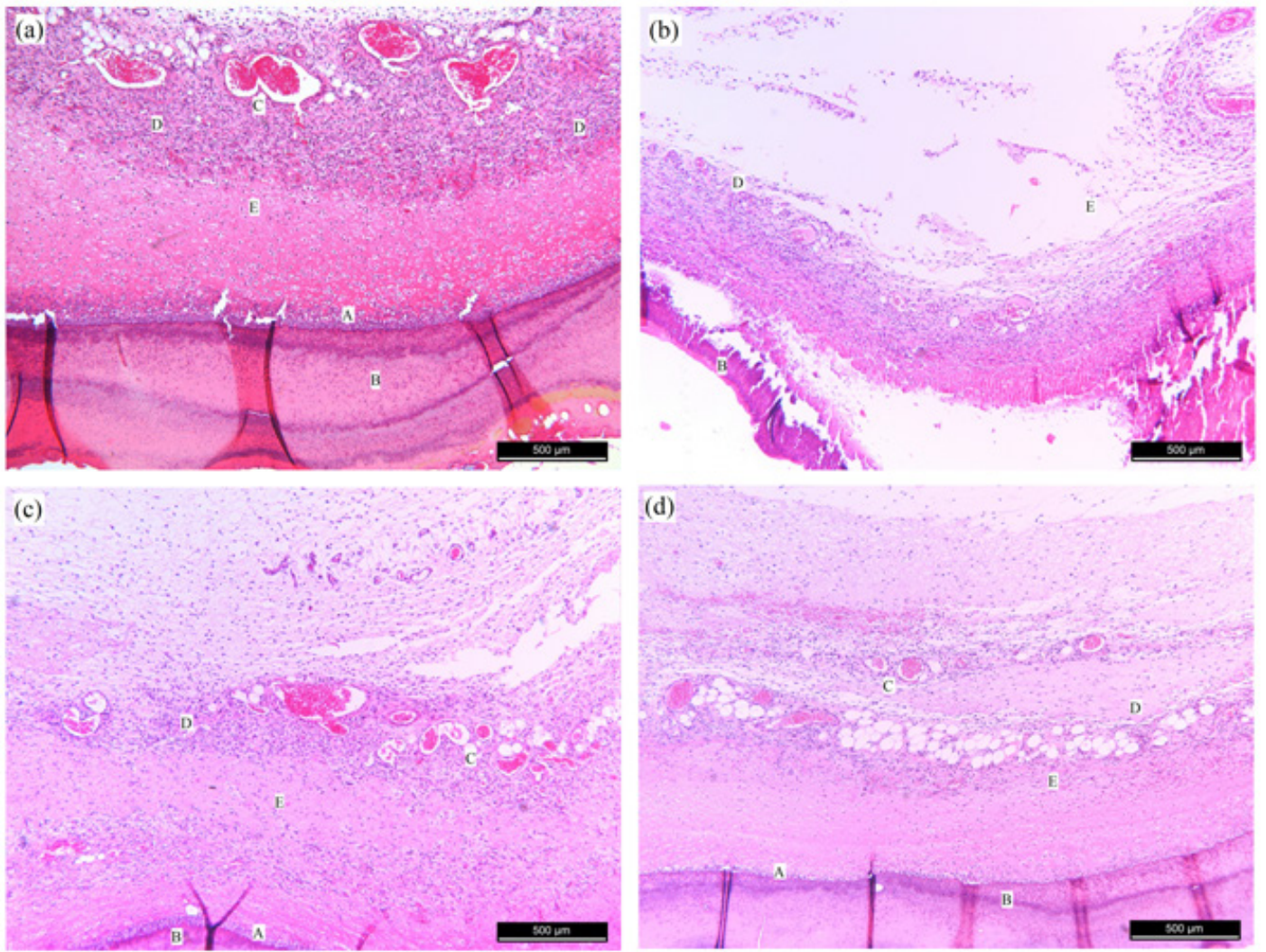

Figure 5 3-day period, (A) - Gl shows complete and in formation neovascularization, crust, organized granulation tissue and moderate inflammatory reaction in the epithelial healing process; (B) - Gll shows absence of epithelium, crust, disorganized granulation tissue, moderate inflammatory reaction and early neovascularization; (C) - GIII shows complete and in formation neovascularization, granulation tissue in organization and medium inflammatory reaction in the epithelial healing process; (D) - GIV shows complete and in formation neovascularization, crust, granulation tissue in organization and medium inflammatory reaction in the epithelial healing process. Epithelium (A), crust (B), neovascularization (C), inflammatory infiltrate (D), granulation tissue $(E)$ and keratin layer (F). Staining: H\&E.

\section{In vivo experiment}

Studies of the wound healing process use, basically, three general parameters, namely wound histological analysis, including cell and extracellular matrix observation, quantification of the reepithelized area, and macroscopic wound qualification (which shows the presence of clot, secretions, hyperemia and hair).$^{38} \mathrm{~A}$ large quantity of exudate and toxin is observed in wound contaminations and may retard the healing process and cause systemic infections. ${ }^{39}$ Different wound dressings have been developed due to the existence of several types of acute and chronic wounds caused by multiple pathophysiologies, which affect the soft tissues in different chronicity levels and wound healing phases. Alternative methods of wound closure have 
been designed and refined over the past decades. ${ }^{40}$ An ideal wound dressing should prevent exacerbated healing, promote no foreign body reaction, and be easily removed, if necessary, with no damage to the newly formed tissue. ${ }^{41}$ Healing depends on two pillars, namely vascularization and capacity of the cell to synthesize collagen. Vascularization promotes the transport of cells to the inflammatory site and supply of nutrients and oxygen. Furthermore, epithelial integrity is an important parameter for the definition of time and effectiveness of second-intention healing. ${ }^{42}$ Several factors can influence the stages of healing, and the main local ones include bleeding, oxygen tension and infection. Some extrinsic factors are surgical technique, topical antiseptics and dressings. ${ }^{43}$ Regarding wound dressings, several types based on plant herbs, ${ }^{44,45}$ hydrocolloid, alginate and collagen ${ }^{46}$ have been developed and can be applied as ointment, film, ${ }^{47}$ foam and gel ${ }^{48}$ for several treatments. ${ }^{49}$ This manuscript reports on the development of a wound dressing for tissue repair based on bacterial cellulose with C. officinalis and J. caroba.

Hydrogels promote suitable physiological conditions for wound healing ${ }^{50}$ and a barrier against microorganisms and enable the permeation of only water and nutrients. They also retain water; therefore, a favorable environment for wounds must be maintained for tissue repair. Epidermal cells can migrate at a $0.5 \mathrm{~mm} /$ day rate along a moist wound surface, which is twice faster than a crust on dry wounds. ${ }^{51}$ Hydrogels have been indicated for the treatment of deep and contaminated wounds with high amounts of exudates. ${ }^{52}$ Their soft and rubbery feature minimizes irritation in adjacent tissue. ${ }^{53}$ Some positive points for the topical covers are: is not necessary to make sutures, they have a quick application and do not invade surrounding tissues. These characteristics favor the obtaining of efficient results when hydrogel is used for wound repair. ${ }^{8}$ The characteristics of bacterial cellulose, as transparent wound dressing, easy application and removal can be advantageous in cases of exacerbated healing (fibrosis) and/or exudates. ${ }^{41}$ Bacterial cellulose has been successfully used as a dressing for chronic ulcers, burns, dermabrasion and skin donor areas. ${ }^{54}$ Barud ${ }^{37}$ developed a wound dressing based on $\mathrm{BC} /$ propolis that proved an effective material in infected wounds because of its antibacterial action. The use of propolis and extract of $J$. caroba leaves, which show a dark coloration, causes the dressing to lose transparency. Since $C$. officinalis extract is clearer because it originates from the white flowers of the plant, transparency is maintained. However, $\mathrm{BC} / \mathrm{CO}$ and $\mathrm{BC} / \mathrm{JC}$ showed efficient wound dressings and promoted a faster and better re-epithelialization within 7-15 days (critical periods) of postoperative period in relation to other groups. They also showed easy application and good adhesion to the wound bed and caused no complications during the healing period. $\mathrm{BC} / \mathrm{CO}$ yielded a macroscopically better result of tissue repair in relation to other hydrogels and exhibited most desirable characteristics for an 'ideal dressing'. It was also suitable for the cleaning of dry wounds and promoted auto lytic debridement. The hydrogels were permeable to metabolites, decreased the temperature of the wound bed, which led to a marked reduction in pain, and were not reactive with the biological tissue. Moreover, they left no residue on the wound bed and improved the re-epithelialization of wounds.

No group showed formation of purulent exudate on the wounds. Such exudate is a sign of exacerbated inflammatory response probably caused by infection on the site or failure of material due to its cytotoxicity. The non-formation of the purulent exudate proved the good response of the organism to the coatings and enabled a more appropriate cicatricial process. This result is probably due to the excellent properties of bacterial cellulose, together with the antibacterial, anti-inflammatory and antifungal characteristics of the extracts of the medicinal plants present in the hydrogels. The mean values \pm standard error of the wound sizes in relation to the experimental periods and groups are shown in Figure 8. The values in percentage were based on a previous study conducted by Sanchez. At days 3 and 7 (critical period) (Figures 5 \& 6), all wounds showed a decrease in size, however, $\mathrm{BC} / \mathrm{CO}$ showed a statistically significant difference $(\mathrm{p}<0.05)$ in comparison to the other groups. The lesions remained clean and a granulation tissue was formed mainly in the margins. Some studies have shown the formation of a larger vascular network in granulation tissue contributes toward a faster and better healing process due to the greater influx of nutrients and efflux of metabolites from the area of the wound. At day 15 (Figure 9), the size of the wounds had decreased and a complete reepithelization was observed only in the 3 groups treated. A statistically significant difference was detected in the tissue repair among the groups $(\mathrm{p}<0.05)$. $\mathrm{BC} / \mathrm{CO}$ and $\mathrm{BC} / \mathrm{JC}$ showed no statistical difference, however, pure $\mathrm{BC}$ hydrogel revealed a statistically significant difference $(\mathrm{p}<0.05)$ in comparison to the negative control group. At day 30 (Figure 10), no statistical differences were observed among the groups. Since the results of tissue repair were parametric, the Two-way ANOVA test was applied and showed a statistical difference between the treatments $(\mathrm{p}=0.0001)$. Tukey post-test revealed the best treatment in each period.

A treatment with $\mathrm{BC}-\mathrm{CO}$ promoted a statistical difference for tissue repair $(\mathrm{p}<0.05)$ in periods of three and seven days (critical periods), in comparison to clot-filled wounds (control) and BC-P. Observed the closure of wounds in a $\mathrm{BC}$ composite with chitosan and silver nanoparticles in a 25 -day period. The toxic effects of silver on reepithelialization and cell proliferation must be taken into account $^{61}$ and may justify a late closure. The dressings caused no exacerbation or prolongation of the inflammatory process because of their biological and physical properties and non-toxic, biocompatible and hydrophilic nature. An important aspect is their ability to contain exudate in the wound and form a capsule that immobilizes pathogenic microorganisms, which might cause an infectious process, hence, exacerbation and prolongation of inflammatory reactions. Although this study has revealed the test products exhibit no irritant properties on healthy skin even after repeated applications, some of their ingredients can cause skin sensitization after repeated uses over a longer period. Marigold is known to cause contact dermatitis after repeated applications due to sensitization. In a survey on the prevalence of sensitization to marigold in 443 consecutive patients, $2 \%$ reacted positively in the patch testing. ${ }^{62}$ In the current study, the hydrogels with the extracts showed no irritating properties probably due to their ideal concentration used for dressing preparations. The initial stage of healing, called inflammatory, is vital to the repair process. The role of the inflammatory phase, including the migration of neutrophils to tissues, has been debated in the literature, and most researchers believe neutrophils eliminate debris (cell fragments), protect the wound against infection, and promote healing. Neutrophil displacement begins immediately after a tissue injury and is shortlived, reaching a concentration peak in only 12 hours.

ANOVA was applied for the degree of inflammation and showed a statistical difference $(\mathrm{p}=0.037)$ between the treatments for the threeday period (critical period). T-test detected the group with best results and the treatment with the bacterial cellulose hydrogel with Calendula officinalis $(\mathrm{BC} / \mathrm{CO})$ showed a lower degree of inflammation $(\mathrm{p}=0.030)$ in relation to the hydrogel treatment of Pure Bacterial Cellulose (BC/P). Kruskal-Wallis test was applied for the degree of tissue repair standard (quality, quantity and orientation of collagen 
fibers) and showed a statistical difference $(p=0.020)$ between the treatments for the seven-day period. Dunn post-test revealed the best group. The bacterial Cellulose hydrogel treatment with Calendula officinalis $(\mathrm{BC} / \mathrm{CO})$ achieved a better result than the treatments with Pure Bacterial Cellulose Hydrogel $(\mathrm{BC} / \mathrm{P})(\mathrm{p}=0.0090)$ and Bacterial
Cellulose Hydrogel with Jacaranda caroba $(\mathrm{BC} / \mathrm{JC})(\mathrm{p}=0.014)$. Kruskal-Wallis test was applied for the degree of tissue repair pattern (reconstitution of the epithelium) and showed no significant statistical difference between the treatments.
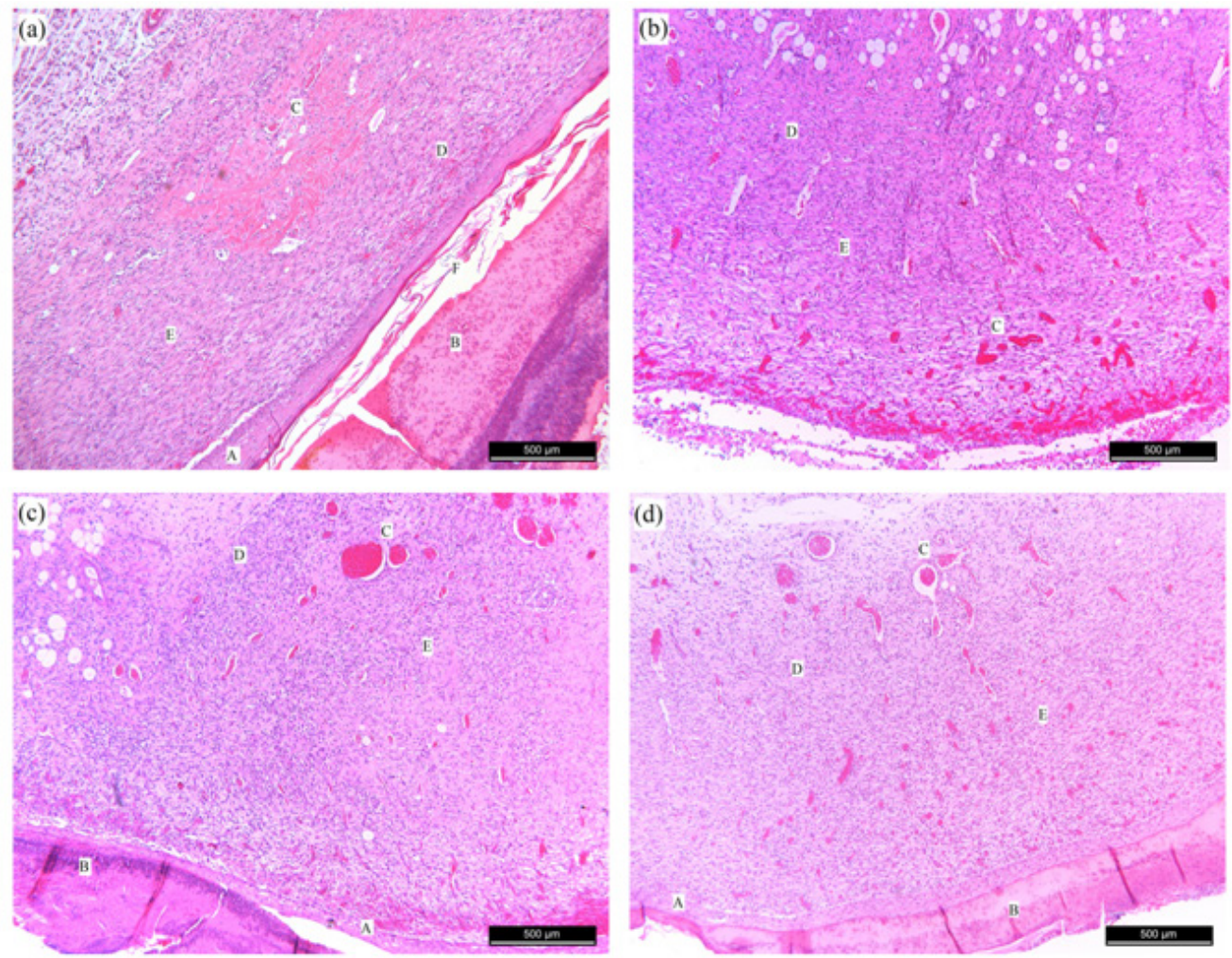

Figure 6 7-day period, (A) - Gl shows complete and in formation neovascularization, crust, organized granulation tissue, keratin layer and moderate inflammatory reaction in the complete epithelium; (B) - Gll shows absence of epithelium, complete and in formation neovascularization, organized granulation tissue, moderate inflammatory reaction; (C) and (D) - GIII and GIV show complete and in formation neovascularization, crust, organized granulation tissue and moderate inflammatory reaction in the epithelial healing process. Epithelium (A), crust (B), neovascularization (C), inflammatory infiltrate (D), granulation tissue (E) and keratin layer (F). Staining: H\&E.

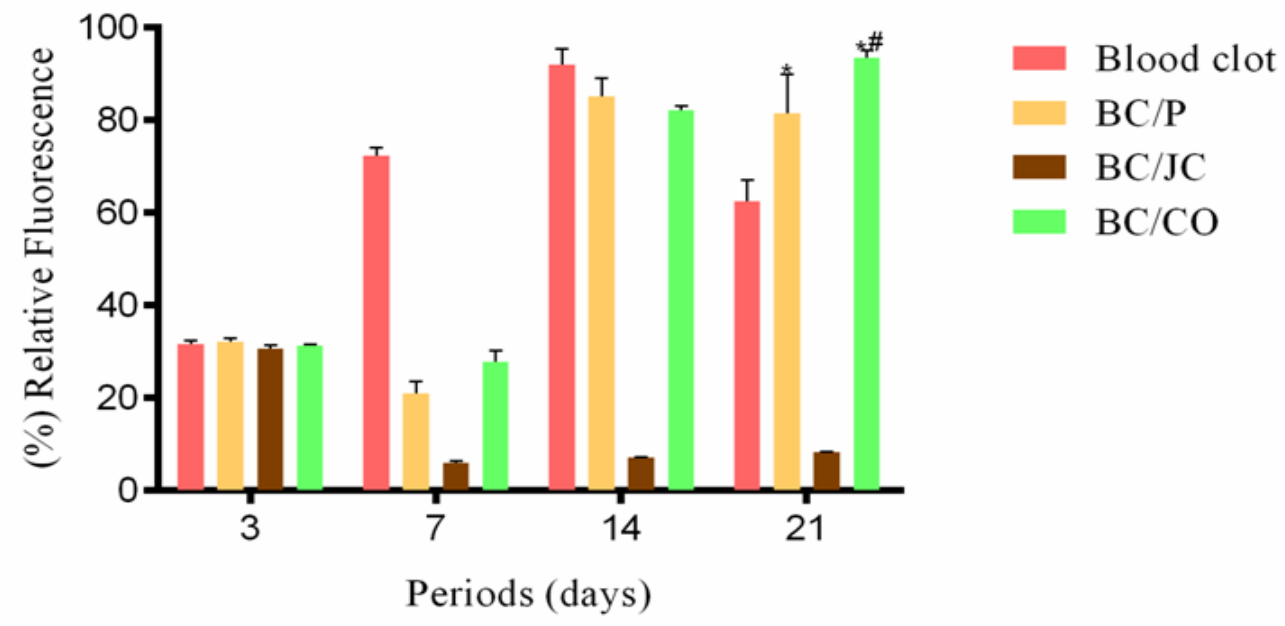

Figure 7 Cell proliferation of L929 fibroblasts in contact with hydrogel extracts at $10 \mathrm{~m} / \mathrm{v} \%$.The higher the relative fluorescence (\%), the greater the number of viable cells. The color bars represent the averages and the black bars represent the Standard Error of Averages. * $\mathrm{n}<0.05$ compared to untreated cells (control). ** $\mathrm{n}<0.000$ l compared to different hydrogels. 


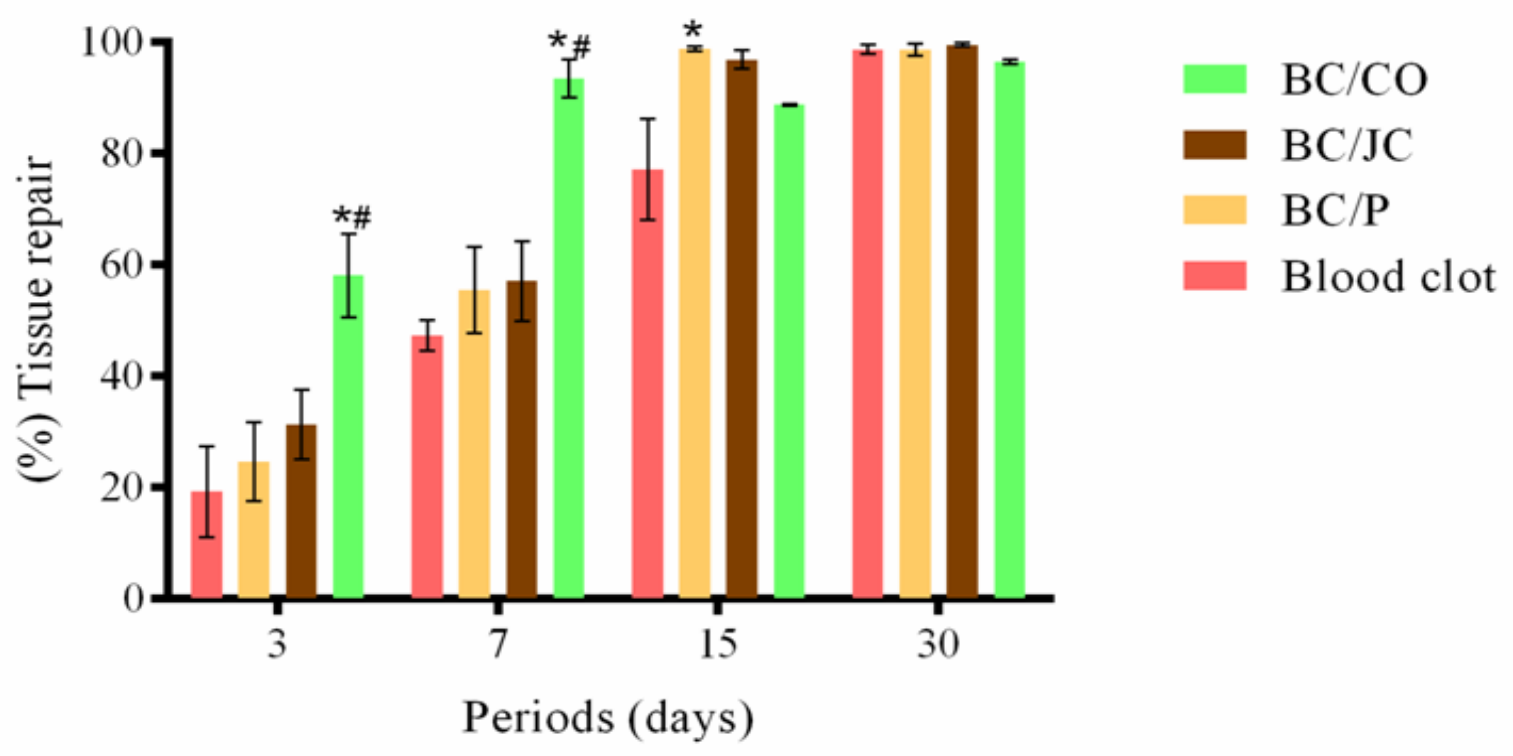

Figure 8 Values measured for the tissue repair of wounds of GI, GII, GIII and GIV groups for experimental periods of 3, 7, I5 and 30 days.Values are expressed as mean \pm standard error; ${ }^{*}<0.05$ in comparison to blood clot. $\# p<0,05$ in comparison to $B C / P$.
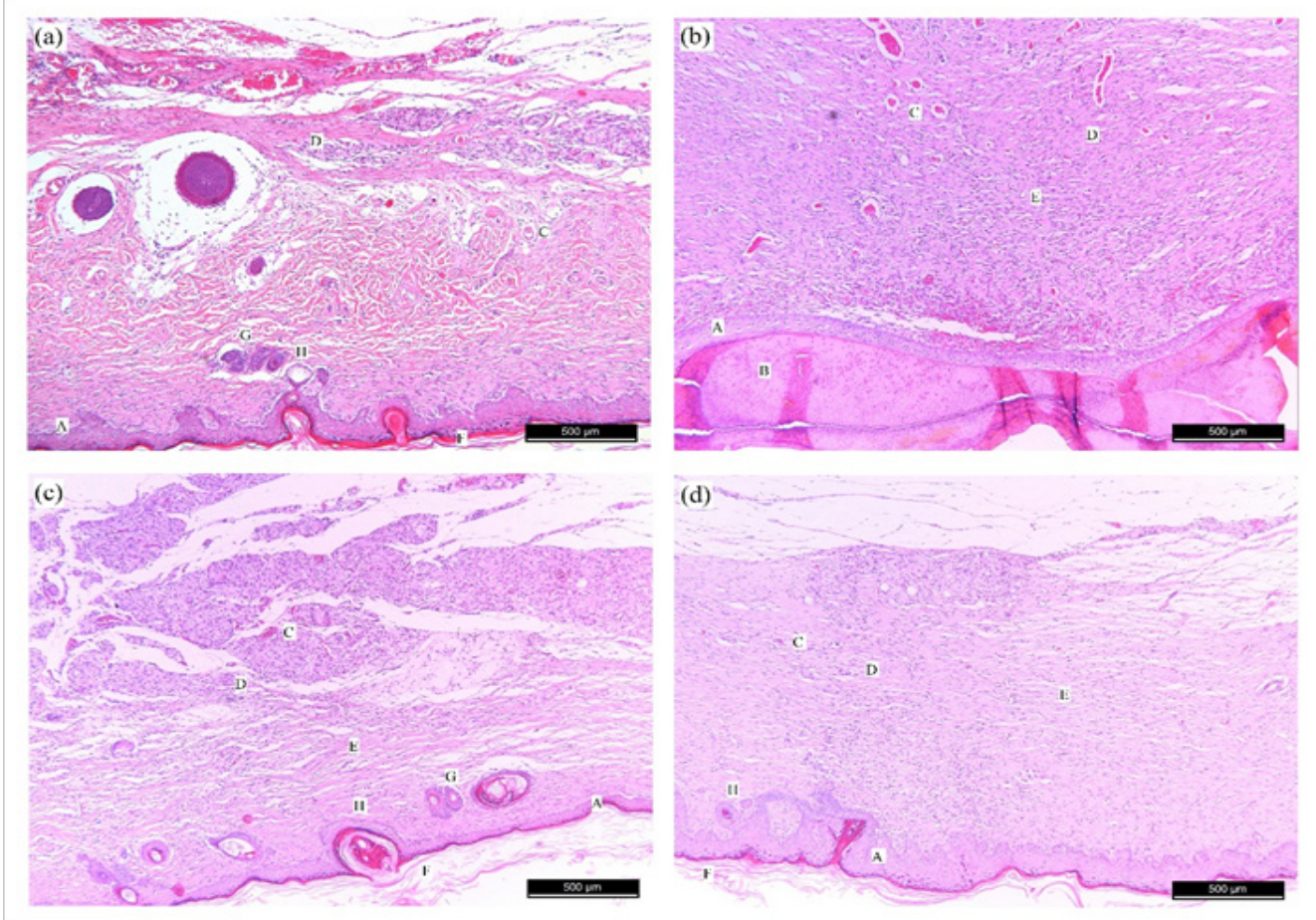

Figure 9 15-day period, (A) - Gl shows complete and in formation neovascularization, organized granulation tissue, medium inflammatory reaction in the complete epithelium, keratin layer, dermis repair with hair follicle and glands; (B) - Gll shows complete and in formation neovascularization, organized granulation tissue, crust, moderate inflammatory reaction in the complete epithelium; (C) - GIII shows complete and in formation neovascularization, organized granulation tissue, moderate inflammatory reaction in the complete epithelium, keratin layer, hair follicle and glands; (D) - GIV shows complete and in formation neovascularization, organized granulation tissue, medium inflammatory reaction in the complete epithelium, keratin layer and hair follicle. Epithelium (A), crust $(B)$, neovascularization $(C)$, inflammatory infiltrate $(D)$, granulation tissue $(E)$ keratin layer $(F)$, glands $(G)$ and hair follicle $(H)$. Staining: $H \& E$. 

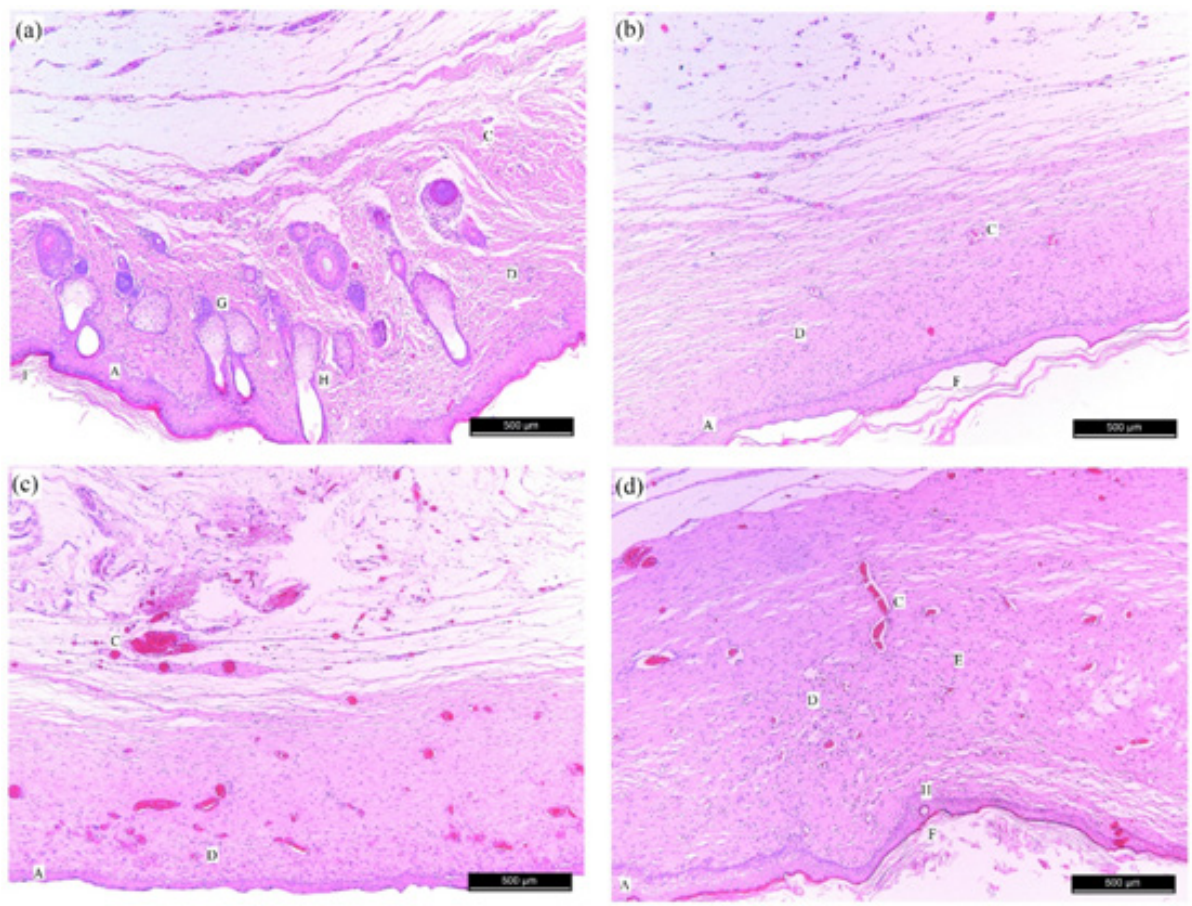

Figure 10 - 30-day period, (a) - Gl shows complete and in formation neovascularization, organized granulation tissue, mild inflammatory reaction in the complete epithelium, keratin layer, hair follicle and glands; (b) and (d) - GII and GIV show complete and in formation neovascularization, organized granulation tissue, medium inflammatory reaction in the complete epithelium and keratin layer; (c) - GIII shows complete and in formation neovascularization, organized granulation tissue, mild inflammatory reaction in the complete epithelium. Epithelium (A), crust (B), neovascularization (C), inflammatory infiltrate (D), granulation tissue $(E)$ keratin layer $(F)$, glands $(G)$ and hair follicle $(H)$. Staining: H\&E.

\section{Conclusion}

$\mathrm{BC} / \mathrm{CO}$ and $\mathrm{BC} / \mathrm{JC}$ hydrogels are developed according to a practical and fast technique. They are biocompatible, of easy application and adhesiveness to the wound area, and their properties favor a the humid environment, faster tissue repair, less severe inflammation during critical periods in relation to other groups, and do not damage granulation. $\mathrm{BC} / \mathrm{CO}$ maintained the semitransparent characteristic of $\mathrm{BC}$ after the addition of its dye. $\mathrm{BC} / \mathrm{JC}$ showed a faster re-epithelialization (within 7 days) in comparison to the other treated groups, which exhibited this characteristic in the later period (15 days). SEM analysis revealed the presence of interconnected pores in the hydrogels, even after the addition of tinctures to BC. $\mathrm{BC} / \mathrm{P}$ and $\mathrm{BC} / \mathrm{JC}$ showed apparently larger pores, which favors the passage of cells for a faster re-epithelialization. TG analysis indicated the hydrogels with incorporated plant dyes displayed better thermal properties than BC/P. BC with dyes $(10 \%)$ showed no toxicity to cell proliferation, which confirmed the concentration of dyes used, was favorable. $\mathrm{BC} / \mathrm{CO}$ and $\mathrm{BC} / \mathrm{JC}$ hydrogels are promising biomaterials for the tissue regeneration of complex wounds, mainly in the initial periods (chronic period) of healing, due to their favorable results in relation to the control groups (positive and negative).

\section{Acknowledgements}

The authors acknowledge the financial support provided by Brazilian agency CAPES.

\section{Conflicts of interest}

Authors declare that there is no conflict of interest.

\section{References}

1. Ravichandran R, Venugopal JR, Sundarrajan S, et al. Composite polyL-lactic acid/poly- $(\alpha, \beta)$-DL-aspartic acid/collagen nanofibrous scaffolds for dermal tissue regeneration. Mat Sci Eng. 2012;C32(6):1443-1451.

2. Groeber F, Holeiter M, Hampel M, et al. Skin tissue engineering - in vivo and in vitro applications. Adv Drug Deliv Rev. 2011;63(4-5):352366.

3. Magalhães MS, Fechine FV, Macedo RN, et al. Effect of a combination of medium chain triglycerides, linoleic acid, soy lecithin and vitamins A and E on wound healing in rats. Acta Cir Bras. 2008;23(3):262-269.

4. Jones SA, Bowler PG, Walker M, et al. Controlling wound bioburden with a novelsilver-containing Hydrofiber_dressing. Wound Repair Regen. 2004;12(3):288-294.

5. Kanani AG, Bahrami SH, Taftei HA, et al. Effect of chitosan-polyvinyl alcohol blend nanofibrous web on the healing of excision and incision full thickness wounds. IET Nanobiotechnol. 2010;4(4):109-117.

6. Klemm D, Heublein B, Fink HP, et al. Cellulose: fascinating biopolymer and sustainable raw material. Angewandte Chemie International Edition English. 2005;44(22):3358-3393.

7. Czaja WK, Young DJ, Kawecki M, et al. The future prospects of microbial cellulose in biomedical applications. Biomacromolecules. 2007;8(1):1-12.

8. Fontana JD, de Souza AM, Fontana CK, et al. Acetobacter cellulose pellicle as a temporary skin substitute. Applied Biochemistry and Biotechnology. 1990;24-25:253-264.

9. Wouk AF, Diniz JM, Cirio SM, et al. Membrana biológica (Biofill) estudo comparativo com outros agentes promotores da cicatrização de pele em suínos: aspectos clínicos, histopatológicos e morfométricos. Archives of Veterinary Science. 1998;3(1):31-37. 
10. Andrade FK, Costa R, Domingues L, et al. Improving bacterial cellulose for blood vessel replacement: Functionalization with a chimeric protein containing a cellulose-binding module and an adhesion peptide. Acto Biomaterialia. 2010;6(10):4034-4041.

11. Preethi KC, Kuttan G, Kuttan R. Anti-inflammatory activity of flower extract of Calendula officinalis Linn. And its possible mechanism of action. Indian Journal of Experimental Biology. 2009;47(2):113-120.

12. Schulz V, Hansel R, Tyler VE. Rational Phytotherapy. New York. Springer: 1998 .

13. Zitterl-Eglseer K, Sosa S, Jurenitsch J, et al. Anti-oedematous activities of the main triterpendiol esters of marigold (Calendula officinalis L). $J$ Ethnopharmacol. 1997;57:139-144.

14. Di Stasi LC, Hiruma-Lima CA. Plantas medicinais na Amazônia e na Mata Atlântica. 2nd edn. Botucatu, SP. UNESP; 2002:451-452 .

15. Botion LM, Ferreira AV, Côrtes SF, et al. Effects of the brazilian phytopharmaceutical product Ierobina on lipid metabolism and intestinal tonus. Journal of Ethnopharmacology. 2005;102(2):137-142.

16. ASTM F981-04. Standard Practice for Assessment of Compatibility of Biomaterials for Surgical Implants with Respect to Effect of Materials on Muscle and Bone. West Conshohocken, PA. ASTM International; 2004 .

17. Copp BR. Antimycobacterial natural products. Natural Products Report. 2003;20(6):535-557.

18. Higuchi CT, Pavan FR, Leite CQF, et al. Triterpenes and antitubercular activity of Byrsonima crassa. Química Nova. 2008;31(7):171921.

19. Simões CMO, Shenkel EP, Gosmann G, et al. Pharmacognosy: from plant to medicine, Porto Alegre / Florianópolis. UFRGS/UFSC; 2004:579-604.

20. Stivala LA1, Savio M, Cazzalini O, et al. Effect of $\beta$-carotene on cell cycle progression of human fibroblasts. Carcinogenesis. 1996;17:23952401.

21. Araújo CBO, Santos AM, Fernandes LA, et al. Use of organic fertilization and mulching in the production of calendula (Calendula officinalis L.). Rev Bras Plantas Med. 2009;1(2):117-123.

22. Annabi N, Nichol JW, Zhong X, et al. Controlling the porosity and microarchitecture of hydrogels for tissue engineering. Tissue Eng Part B Rev. 2010;16:371-383.

23. O'Brien FJ, Harley BA, Yannas IV, et al. The effect of pore size on cell adhesion in collagen-GAG scaffolds. Biomaterials. 2005;26(4):433441.

24. Cienfuegos F, Vaitsman D. Instrumental Analysis, Rio de Janeiro. 2000:66.

25. Grande CJ, Torres FG, Gomez CM, et al. Development of Selfassembled bacterial cellulose-starch nanocomposites. Materials Science and Engineering. 2009;29(4):1098-1104.

26. Tonhi E, Plepis AMG. Obtaining And Characterization Of CollagenChitosan Blendas. Química Nova. 2002;25(6):943-948.

27. Chen J, Liu Y, Xiong DY, et al. Preparation and photochromic behavior of crosslinked polymer thin films containing polyoxometalates. Thin Solid Films. 2008;516:2864-2868.

28. Falcão SC, Coelho ARB, Almeida EL, et al. Processo modificado de reprodução e amplificação de imagem para mensuração de área por planimetria: aplicação em feridas planas produzidas em cães, tratadas por curativos oclusivos de pele de rã. Braz J Vet Res Anim. Sci. 2001;38:165-169.

29. Houghton PJ, Hylands PJ, Mensah AY, et al. In vitro tests and ethnopharmacological investigations: wound healing as an example. Journal of Ethnopharmacology. 2005;100(1-2):100-107.
30. Lauto A, Mawad D, Barton M, et al. Photochemical tissue bonding with chitosan adhesive films. BioMedical Engineering OnLine. 2010;9(47):2-11.

31. Panerari AD, Costa HO, Souza FC, et al. Avaliação da resposta inflamatória traqueal ao curativo de celulose bacteriana após escarificação cirúrgica em coelhos. Revista Brasileira de Otorrinolaringologia. 2008;74(4):512-522.

32. Duynstee ML, Verwoerd-Verhoef HL, Verwoerd CD, et al. The dual role of perichondrium in cartilage wound healing. Plastic and Reconstructive Surgery. 2002;110(4):1073-1079.

33. Waldorf H, Fewkes J, Wound healing. Advances in Dermatology. 1995;10:77-96.

34. Inngjerdingen K1, Nergård CS, Diallo D, et al. An ethnopharmacological survey of plants used for wounds healing in Dogoland, Mali, West Africa. Journal of Ethnopharmacology. 2004;92(2-3):233-244.

35. Mensah AY, Houghton PJ, Dickson RA, et al. In Vitro evaluation of effects of two ghanaian plants relevant to wound healing. Phytotherapy Research. 2006;20(11):941-944.

36. Queen D, Orsted H, Sanada H, et al. A dressing history. International Wound Journal. 2004;1(1):59-77.

37. Barud Hda S, de Araújo Júnior AM, Saska S, et al. Antimicrobial brazilian Propolis (EPP-AF) containing biocellulose membranes as promising biomaterial for skin wound healing. Evidence-Based Complementary and Alternative Medicine. 2013: 703024.

38. Falabella AF. Debridement and wound bed preparation. Dermatologic Therapy. 2006;19(6):317-325.

39. Eccleston GM. Wound dressings. In: Aulton ME, Editor. Pharmaceutics: The science of dosage form design. 3rd edn. UK: Churchill Livingstone; 2007:264-271.

40. Kickhöfen B, Wokalek H, Scheel D. Chemical and physical proprieties of a hydrogel wound dressing. Biomaterials. 1986;7(1): 67-62

41. Araújo CF, Souza Filho ZA, Greca FH, et al. Efeitos do agarolâ e do triglicerilâ sobre a cicatrização de pele: estudo. Acta Cirúrgica Brasileira. 1994;13(4):231-236.

42. Anderson JM, Langone JJ. Issues and perspectives on the biocompatibility and immunotoxicity evaluation of implanted controlled release systems. Journal of Controlled Release. 1999;57(2):107-113.

43. Costa HO, Souza FC. Evaluation of tissue regeneration of pig skin submitted to thermal injury followed by Biotissue ${ }^{\circledR}$ placement. Técnicas em Otorrinolaringologia. 2005;23(3):23-27.

44. Czaja W, Krystynowicz A, Bielecki S, et al. Microbial cellulose-the natural power to heal wounds. Biomaterials. 2006;27(2):145-151.

45. Sevastjanova NA, Mansurova LA, Dombrovska LE. Biochemical characterization of connective tissue reaction to synthetic polymer implants. Biomaterials. 1987;8(4):242-247.

46. Sanchez F. Evaluation of tissue repair process in chronic ulcers using bacterial cellulose dressings associated or not with laser therap. USP; 2012.

47. Webb C, Dyson M. The effect of $880-\mathrm{nm}$ low level laser energy on human fibroblast cell numbers: a possible role in hipertrophic wound healing. J Photochem Photobiol B. 2003;70:39-44.

48. Reider N, Komericki P, Hausen BM, et al. The seamy side of natural medicine: Contact sensitization to arnica (Arnica montana L) and marigold (Calendula officinalis L). Contact Dermatitis. 2001;45:269 272

49. Al-Watban FA, Delgado GD. Burn healing with a diode laser: $670 \mathrm{~nm}$ at different doses as compared to a placebo group. Photomed Laser Surg. $2005 ; 23: 245-250$. 
50. Winter GD. Formation of the scab and the rate of epithelialization of superficial wounds in the skin of the young domestic pig. Nature. 1962;193:293-294.

51. Vogt PM, Andree C, Breuing K, et al. Dry, moist and wet skin wound repair. Annals of Plastic Surgery. 1995;34(5):493-500.

52. Hoenich N. Cellulose for medical applications: past, present, and future. BioResources. 2006;1(2):270-280.
53. Osman AS, Souza FC, Dolci JE. Experimental study on the application of cellulose film (Bionext $\left.{ }^{\circledR}\right)$ in a bloody rabbit nasal resection area. Técnicas em Otorrinolaringologia. 2007;25(4):304-311.

54. Wan YZ, Huang Y, Yuan CD, et al. Biomimetic synthesis of hydroxyapatite/bacterial cellulose nanocomposites for biomedical applications. Material Science and Engineering. 2007;27(4):855-864. 